\title{
Artificial fertilization of oocytes and sperm activation in pacu: effects of the spermatozoa:oocyte ratio, water volume, and in natura semen preservation
}

\author{
Eduardo Antônio Sanches ${ }^{1}$, Diego Mendes Baggio², Pitágoras Augusto Piana², Bruno Estevão \\ de Souza ${ }^{3}$, Robie Allan Bombardelli²
}

${ }^{1}$ Centro de Aquicultura, Universidade Estadual Paulista Julio de Mesquita Filho, 14884-900, Jaboticabal, SP.

2 Curso de Engenharia de Pesca, Universidade Estadual do Oeste do Paraná, 85900-903, Toledo, PR.

3 Instituto Federal do Paraná, 85860-000, Foz do Iguaçu, PR.

\begin{abstract}
The objective of this work was to investigate artificial fertilization and the duration of sperm motility in pacu with different insemination doses, water volume, and in natura semen preservation. It was carried out four experimentsfor evaluation of insemination doses $\left(7 \times 10^{3}, 7 \times 10^{4}, 7 \times 10^{5}, 7 \times 10^{6}\right.$, and $7 \times 10^{7}$ spermatozoa oocytes $\left.^{-1}\right)$ on the artificial fertilization of oocytes; the effect of water volume $\left(0.5,15.0,30.0,45.0\right.$, and $60.0 \mathrm{~mL}$ water mL $\mathrm{mL}^{-1}$ of oocyte) with insemination doses of 105,481 and 210,963 spermatozoa oocytes $^{-1}$; the effect of semen dilutions $(0.005,0.05,0.5$, and $5.0 \mu \mathrm{L}$ semen $\mathrm{mL}^{-1}$ of water) on sperm motility duration; and the effect of storage at $15^{\circ} \mathrm{C}$ for $9 \mathrm{~h}$ on sperm motility duration and sperm survival ratio. The highest results obtained were: insemination doses from $7 \times 10^{3}$ to $7 \times 10^{7}$ spermatozoa oocytes $^{-1}$; from 15 to $60 \mathrm{~mL}$ water $\mathrm{mL}^{-1}$ of oocytes; semen dilution of $0.005 \mu \mathrm{L}$ semen/mL water and $98.65 \%$ sperm survival until $2 \mathrm{~h} 45 \mathrm{~min} 36 \mathrm{~s}$ preservation time. Preservation at $15^{\circ} \mathrm{C}$ for $9 \mathrm{~h}$ does not influence sperm motility duration. The highest fertilization rates can be observed by using 0.27 to $270 \mu \mathrm{L}$ semen $\mathrm{mL}^{-1}$ of oocytes with 15 at $60 \mathrm{~mL}$ water for activation.
\end{abstract}

Key Words: fish, gametes, insemination doses, Myleinae, reproduction

\section{Fertilização artificial de ovócitos e ativação espermática em pacus: efeito da razão espermatozoide:ovócito, volume de água e preservação do sêmen in natura}

\begin{abstract}
RESUMO - Objetivou-se foi avaliar a fertilização artificial e a duração da motilidade espermática em pacus com diferentes doses inseminantes, volumes de água e preservação do sêmen in natura. Foram realizados quatro experimentos para avaliação do efeito de doses inseminantes $\left(7 \times 10^{3}, 7 \times 10^{4}, 7 \times 10^{5}, 7 \times 10^{6}\right.$ e $7 \times 10^{7}$ espermatozoides ovócito-1) sobre a fertilização artificial dos ovócitos; do efeito do volume de água $\left(0,5 ; 15,0 ; 30,0 ; 45,0\right.$ e $60,0 \mathrm{~mL}$ de água $\mathrm{mL}^{-1}$ de ovócitos) com doses inseminantes de 105.481 e 210.963 espermatozoides ovócito-1; do efeito de diluição do sêmen $(0,005 ; 0,05 ; 0,5$ e $5,0 \mu \mathrm{L}$ de sêmen $\mathrm{mL}^{-1}$ de água) sobre a duração da motilidade espermática; e do efeito do armazenamento a $15{ }^{\circ} \mathrm{C}$ por $9 \mathrm{~h}$ sobre a duração da motilidade espermática e o índice de sobrevivência espermática. Os maiores resultados obtidos foram: doses inseminantes entre $7 \times 10^{3}$ e $7 \times 10^{7}$ espermatozoides ovócito ${ }^{-1} ; 15$ a $60 \mathrm{~mL}$ de água $\mathrm{mL}^{-1}$ de ovócitos; diluição de $0.005 \mu \mathrm{L}$ sêmen $\mathrm{mL}^{-1}$ de água e $98,65 \%$ de sobrevivência espermática até o tempo de preservação de $2 \mathrm{~h} 45 \mathrm{~min} 36 \mathrm{~s}$. A preservação a $15^{\circ} \mathrm{C}$ por 9 horas não influencia a duração da motilidade espermática. As maiores taxas de fertilização podem ser observadas no emprego de 0,27 a $270 \mu \mathrm{L}$ de sêmen $\mathrm{mL}^{-1}$ de ovócitos, com 15 a $60 \mathrm{~mL}$ de água para ativação.
\end{abstract}

Palavras-chave: dose inseminante, gametas, Myleinae, peixe, reprodução

\section{Introduction}

Pacu, Piaractus mesopotamicus is a species in the Characidae family, subfamily Myleinae (Nakatani et al. 2001). It is of great importance in commercial fishing in its original region and there is interest in culturing this species in South American countries along the Paraná and Paraguay Rivers (Urbinati \& Gonçalvez, 2005). Because of its importance in Brazilian aquaculture (IBAMA, 2007), pacu has been the focus of research in several areas, including the reproductive management (Urbinati \& Gonçalvez, 2005). However, methods of semen manipulation and preservation and their relationship with successful artificial fertilization require further investigation.

In an attempt to optimize reproductive efficiency in fish, many researchers have determined appropriate insemination doses and sperm concentrations for maximal fertilization (Sanches et al., 2009). An appropriate 
combination of the number of spermatozoa per oocytes, and the activation solution volume used in artificial fertilization are required, as they significantly affect fertilization rate (Souza, 2007). In addition to improving fertilization ratios, these studies will improve preservation programs of genetic biodiversity in pacu and genetic improvement on fish farms (Denniston et al., 2000), as they allow a rational use of gametes, limiting the number of breeding fish in culture stations, and reducing production costs (Bombardelli et al., 2006).

The objective of this study is to evaluate the effects of spermatozoa per oocyte ratios and the water volume on the artificial fertilization rates. It was also assessed the effect of semen preservation on sperm motility duration and sperm survival in pacu, P. mesopotamicus.

\section{Material and Methods}

It was used 17 pacu, P. mesopotamicus breeders, 10 males and 7 females at 7 years of age, provided by Centro de Pesquisa em Aqüicultura Ambiental - CPAA, Toledo, Paraná, Brazil, in December of 2006.

Broodfish were selected in the experimental culture tank. Males that expelled semen upon light abdominal pressure and females with a rounded abdomen and swollen and reddish urogenital papilla were selected. The percentage of oocytes whose germinal vesicles migrate after immersion in Serra solution $\left(60 \mathrm{~mL}\right.$ alcool $90^{\circ} \mathrm{GL} ; 30 \mathrm{~mL}$ formaldeyhd; $10 \mathrm{~mL}$ glacial acetic acid) was determined by an ovarian biopsy (Romagosa et al., 1990). All selected females presented more than $80 \%$ of oocytes with polar vesicles and with the aforementioned characteristics.

The selected animals were transferred to the laboratory. They were weighed, marked, separated by sex in round 2,000-L tanks with constant water renewal ( $\left.750 \mathrm{~L} \mathrm{hour}^{-1}\right)$. Male and female fish were subjected to hormonal induction by injecting carpa pituitary extract (CPE), intraperitoneal via in the pectoral fin region. It was used a total dose of 2.5 and $5.5 \mathrm{mg} \mathrm{kg}^{-1}$ body weight, for males and females respectively (Woynarovish \& Horváth, 1983), splited in two doses. The first one corresponded to $10 \%$ and the second to $90 \%$ of the total. Gametes were collected 240 degree-hours (sum of water temperature over time in hours) after the second hormone injection. Fish were restrained and dried with a tissue, and the abdominal region was massaged in the cephalo-caudal direction.

In experiment 1 , six males and three females with an average weight of $3,000 \pm 992.47$ and 4,110.00 $\pm 608.28 \mathrm{~g}$, respectively, were used. The total volume of semen stripped from each fish was measured after collection, pooled, and analyzed for sperm concentration by cell count in a Neubauer chamber. A 5- $\mu \mathrm{L}$ aliquot of semen was diluted in 5,000 $\mu \mathrm{L}$ buffered formol-saline, according to Streit Junior et al. (2004a), to obtain a final dilution of $1: 1,000$.

Female gametes were collected after a preliminary evaluation in a conditioning tank. Breeders that easily expelled oocytes upon light abdomen pressure were used. The two selected females were transferred to a dry place, and the oocytes were obtained by stripping and later they were tested for fertilization. Oocytes were placed on clean, dry Petri dishes. Those gametes contaminated by urine or feces were discarded.

After collecting female gametes, the relative number of oocytes $\mathrm{mL}^{-1}$ of stripped material per female was determined by counting three $0.1 \mathrm{~mL}$ aliquots of oocytes. After that, 20 aliquots $(2.0 \mathrm{~mL})$ of oocytes were separated for fertilization experiments. They were mixed with several volumes of known semen concentrations and activated with a fixed volume of artesian well water $(30 \mathrm{~mL})(\mathrm{pH}=6.80$; oxygen $=$ $4.26 \mathrm{mg} \mathrm{L}^{-1}$; ammonia $\left.=0.126 \mathrm{mg} \mathrm{L}^{-1}\right)$.

A randomized experimental design was used, with five insemination doses and four replicates. The insemination doses were $7 \times 10^{3}, 7 \times 10^{4}, 7 \times 10^{5}, 7 \times 10^{6}$, and $7 \times 10^{7}$ spermatozoa oocytes ${ }^{-1}$. The eggs were incubated in 20 conical experimental PVC incubators with $2.5 \mathrm{~L}$ of water. It was considered an experimental unit one incubator containing $2.0 \mathrm{~mL}$ of oocytes ( $\cong 2,700$ oocytes). The fertilization ratio was measured $8 \mathrm{~h}$ after oocyte hydration by counting three samples with approximately 250 eggs per incubator.

In experiment 2 , the effect of water volume on the artificial fertilization trials using two spermatozoa doses $\left(105,481\right.$ and 210,963 spermatozoa oocytes $\left.{ }^{-1}\right)$ was tested. The volume ratios tested were $0.5,15.0,30.0,45.0$, and $60.0 \mathrm{~mL}$ of water $\mathrm{mL}^{-1}$ of oocytes. The insemination doses used in this experiment were based on the results from experiment 1 . The fertilization rates were measured to evaluate the effects of the water volume.

In trial 1 , three males and three females weighing $2,800.00 \pm 400.00$ and $4,200.00 \pm 1,479.87 \mathrm{~g}$, respectively, were used. In trial 2 , it was used only one male and one female weighing $3,200 \mathrm{~g}$ and $2,800 \mathrm{~g}$, respectively. In trials 1 and 2, all experimental units contained 2,960 and 2,880 $(2.0 \mathrm{~mL})$ oocytes, respectively.

In experiment 3 , semen from three males from experiment 2 (trial 1) was used. It was used a randomized experimental design containing four dilutions in three replicates. The dilution rates were the activation of spermatozoa with of $0.005,0.05,0.5$, and $5.0 \mu \mathrm{L}$ semen $\mathrm{mL}^{-1}$ water $(0.5,5.0,50.0$ and $500.0 \mu \mathrm{L}$ semen $100 \mathrm{~mL}^{-1}$ water). After dilution, $5 \mu \mathrm{L}$ of 
the mixture was used to evaluate the time needed for loss of motility by approximately $50 \%$ of spermatozoa assessed under light microscopy (400 X) (Sanches et al., 2009).

In experiment 4 , it was used semen from experiment 2 (trial 1). After collection, the semen was transferred to $10.0 \mathrm{~mL}$ glass test tubes and placed in boxes with ice. Sperm survival rate and sperm motility duration were evaluated every 30 minutes after collection until 9 hours of preservation.

The sperm motility duration was measured as in experiment 3 . The sperm survival rate was determined by the eosin-nigrosin staining method (Blom, 1950), mixing $30 \mu \mathrm{L}$ semen and $90 \mu \mathrm{L}$ of each dye and by preparation of a smear. One slide processing was visualized at $400 \times($ light microscopy). Overall, 400 spermatozoa were assessed. Pink cells were dead, whereas unstained cells were live.

Fertilization rates of experiments 1 and 2 were subjected to analysis of variance $(\mathrm{P}<0.05)$ of one-way ANOVA and after that, Tukey's means test were performed by using software Statistica $7.0^{\circledR}$. The presupposed were checked according to Quinn \& Keough (2002).

Sperm motility duration, and sperm survival ratio were subjected to regression analysis $(\mathrm{P}<0.05)$ by using software SAEG 7.0 - Sistema de Análises Estatísticas e Genéticas (UFV, 1997).

\section{Results and Discussion}

In experiment 1 , the mean of collected semen volume was $13.64 \pm 6.82 \mathrm{~mL}$ with a concentration of $3.50 \times 10^{10}$ spermatozoa $\mathrm{mL}^{-1}$. The fertilization rates between insemination doses 7,000 and 7,000,000 sperm oocytes ${ }^{-1}$ remained constant $(\mathrm{P}>0.05)$. For 70,000,000 spermatozoa oocytes $^{-1}$ there was a decrease on fertilization rates $(\mathrm{P}<0.05)$ compared to other insemination doses (Figure 1).

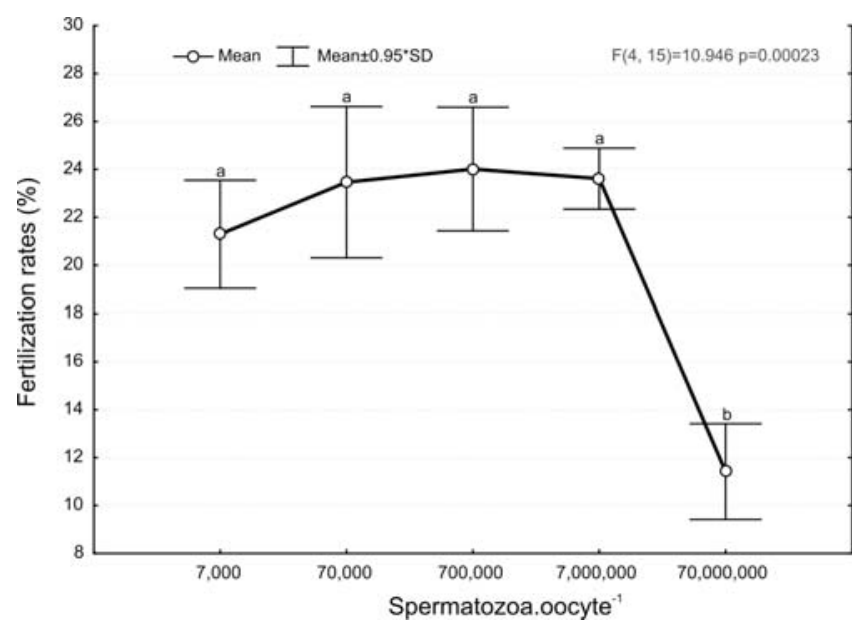

Figure 1 - Fertilization rates of pacu oocytes subjected to various spermatozoa per oocyte ratios in artificial fertilization.
In experiment 2 , trial $1\left(105,481\right.$ spermatozoa oocytes $\left.{ }^{-1}\right)$, the mean of collected semen volume was $12.03 \pm 1.62 \mathrm{~mL}$ with a concentration of $5.30 \times 10^{10}$ spermatozoa $\mathrm{mL}^{-1}$. For trial $2\left(210,963\right.$ spermatozoa oocytes $\left.^{-1}\right)$, the collected semen volume was $9.5 \mathrm{~mL}$ with a concentration of $2.75 \times 10^{10}$ spermatozoa $\mathrm{mL}^{-1}$.

Fertilization ratio results using 105,481 and 210,963 spermatozoa oocytes ${ }^{-1}$ exhibited similar behavior in relation to the volume of water used in the treatments, with constant values ranging from 15 and $60 \mathrm{~mL}$ water $\mathrm{mL}^{-1}$ of oocytes ( $P>0.05$ ) (Figure 2). For both insemination doses, the lowest fertilization rates were observed in $0.5 \mathrm{~mL}$ water $\mathrm{mL}^{-1}$ of oocytes $(\mathrm{P}<0.05)$ (Figure 2$)$.

In experiment 3 , the sperm motility duration was linearl and proportional $(\mathrm{P}<0.05)$ to the increase in the semen dilution for the water (Figure 3 ), with greater results (26.34 $\pm 0.81 \mathrm{~s}$ ) for $0.005 \mu \mathrm{L}$ semen $\mathrm{mL}^{-1}$ water.

In experiment 4 , the sperm motility duration was not affected $(\mathrm{P}>0.05)$ by the semen cooling (Figure 4$)$. However, the survival rate exhibited LRP (Linear Response Plateau) behavior $(\mathrm{P}<0.05)$ with increasing cooling storage time (Figure 4). The survival rates remained constant up to $2 \mathrm{~h} 45 \mathrm{~min} 36 \mathrm{~s}$ for $98.65 \%$ of live spermatozoa. More prolonged storage resulted in an inversely proportional relation between the survival rate and the cooling storage time.

Semen production and sperm concentration of $P$. mesopotamicus brood fish varied among experiments. Viveiros \& Godinho (2009), observed, in their review, variations in semen of this same species of pacu, with collected volume of $5.02 \pm 2.84$ up to $12.1 \mathrm{~mL}$ and semen concentrations of $13.9 \pm 1.3 \times 10^{9}$ up to $37.4 \pm 8.0 \times 10^{9}$ spermatozoa $\mathrm{mL}^{-1}$. These differences are common, inasmuch

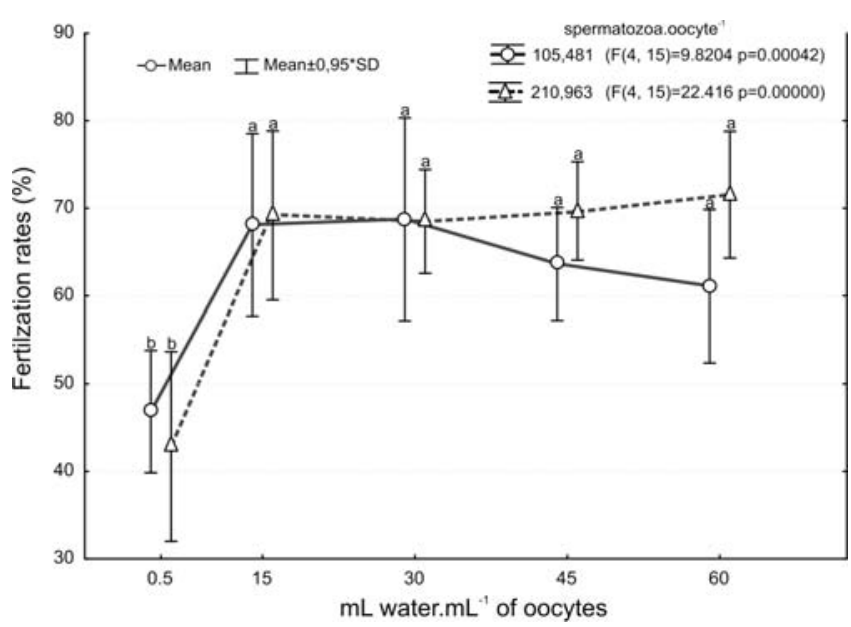

Figure 2 - Fertilization rates of pacu oocytes submitted to two artificial fertilization protocol with various water volumes in 105,481 and 210,963 spermatozoa oocyte ${ }^{-1}$. 


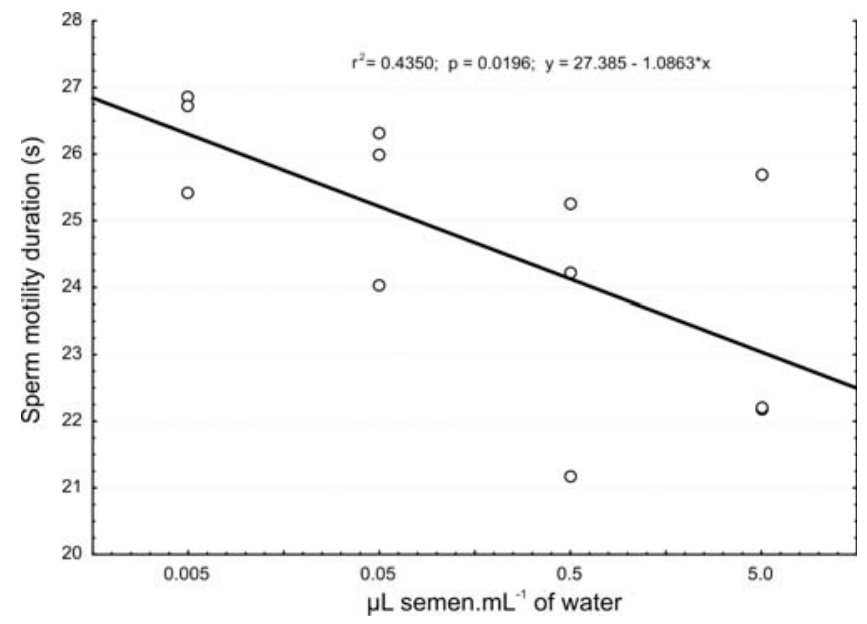

Figure 3 - Sperm motility duration of pacu semen exposed to different semen:water volume ratios of during sperm activation.

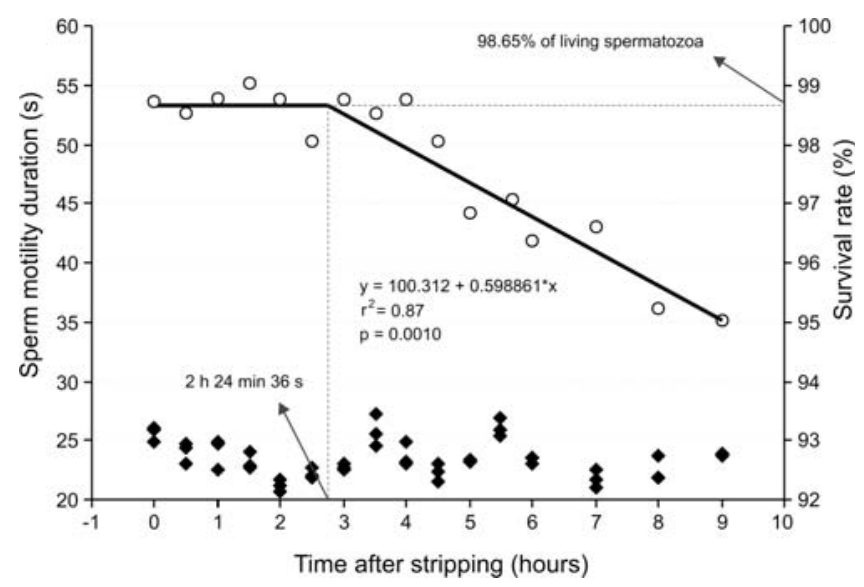

Figure 4 - Effect of in natura and under cooling pacu semen storage on the sperm survival rate and sperm motility duration.

as individual size, time of the year, and the sampling method directly affect these variables (Luz et al., 2001). Furthermore, volume of semen cannot be considered as the total volume of semen collected by the stripping method since it does not guarantee the complete stripping of the semen present in the gonads (Ferreira et al., 2001).

Several factors also determine sperm concentration in fish semen, including the species (Godinho, 2007), the age of the breeder (Bastardo et al., 2004), the use of hormone induction (Zaniboni Filho \& Weingartner, 2007), the hormones used in hormonal induction (Streit Junior et al., 2004b), and the collection time (Borges et al., 2005).

The insemination doses between 7,000 and 7,000,000 spermatozoa oocytes ${ }^{-1}$ did not influence the rates of fertilization by only reducing them down to the dose of
$70,000,000$ spermatozoa oocytes $^{-1}$ (Figure 1). These results are fundamental for the development of production technology of $P$. mesopotamicus because of the importance of this species in aquaculture in Latin America, allowing optimization of breeding through the rational use of gametes.

The trend of fertilization results obtained in this experiment (Figure 1) was different from that found for “dourado", Salminus brasiliensis by Sanches et al. (2009), even though the ideal dose found was 30,722 spermatozoa oocytes $^{-1}$. The appropriate spermatozoa:oocyte ratios vary among species, por example, those found by Bombardelli et al. (2006) and Shimoda et al. (2007) for "jundiá-cinza," Rhamdia quelen and "piabanha," Brycon insignis, respectively, were considerably different from those of $P$. mesopotamicus. Those authors observed that the fertilization rates reached a plateau above the ideal insemination dose and remained constant over 89,497 and 314,418 spermatozoa oocytes $^{-1}$, respectively. According to Rurangwa et al. (1998) and Sanches et al. (2009), fertilization ratios may be affected by low and high spermatozoa:oocyte ratios, and these intervals constrain the fertilization ratio (Tvedt et al., 2001). Besides the spermatozoa per oocyte ratio, other factors can influence the fertilization rates, such as gamete contact time and the fertilization protocol used (Rurangwa et al., 2004). Furthermore, some characteristics, such as oocyte size, spermatozoa swimming distance, sperm motility duration, and micropyle closing time are determinants in the application of insemination doses (Suquet et al., 1995; Chereguini et al., 1999), so as spermatic quality that can be masked with higher inseminations doses (Maria et al., 2004). These characteristics can sharply differ for teleost fish species (Godinho, 2007).

The fertilization rates of oocytes in experiment 2 for 105,481 and 210,963 spermatozoa oocytes ${ }^{-1}$ had a significantly different effect on the treatment (Figure 2). The artificial fertilization rate of oocytes increased up to $15.00 \mathrm{~mL}$ water $\mathrm{mL}^{-1}$ of oocytes. Above that, the fertilization rates remained constant for increasing amounts of water (Figure 2).

Based on the fertilization rates of experiment 2 , the use of large volumes of water as an activating solution, from 15.00 to $60.00 \mathrm{~mL}$ water $\mathrm{mL}^{-1}$ of oocytes, afforded maximum performance in terms of oocyte fertilization rates. However, it is recommended to use low volumes of water in this range for greater ease in artificial fertilization processing and oocyte hydration. Nevertheless, the low fertilization rates observed in treatments with low water volumes were reached by a possible influence of the reduced medium dilution. This low dilution may have resulted in an inefficient reduction of the osmolarity of the fertilization medium (Alavi et al., 2007), which affected spermatozoa activation, or did not provide 
the adequate medium for successful fertilization (Chereguini et al., 1999).

Sperm motility duration of experiment 3 (Figure 3) corroborate the fertilization rates (Figure 1). It was observed that the semen dilution directly affected sperm motility duration and those larger dilutions afforded longer sperm activation times. The fertilization ratios decreased after $7,000,000$ spermatozoa oocyte ${ }^{-1}$, which may be related to the semen dilution. Because the water volume was constant for the treatments, the increase in the spermatozoa per oocyte ratio must have resulted in an inefficient reduction or dilution of the fertilization medium. Sanches et al. (2009) reported similar results for dourado, Salminus brasiliensis semen.

In experiment 4 (Figure 4 ), the in natura cooling storage of semen was conducted up to $2 \mathrm{~h} 45 \mathrm{~min} 36 \mathrm{~s}$ after stripping without any negative effect on spermatozoa, with survival ratios falling sharply thereafter. The preservation of semen at $15^{\circ} \mathrm{C}$ for over this time in these conditions is recommended only if the insemination dose is considered as a function of the reduction of the sperm survival ratio.

Souza (2007) observed that the appropriate use of spermatozoa and water volume ratios in artificial fertilization protocols increases the oocyte fertilization ratios and, consequently, the successful artificial reproduction of curimbatá, Prochilodus lineatus.

\section{Conclusion}

The high fertilization rates of pacu oocytes are observed in the applications of 0,27 at $270 \mu \mathrm{L}$ semen and 15 at $60 \mathrm{~mL}$ of water $\mathrm{mL}^{-1}$ of oocytes. Semen of pacu can be stored in ice box $\left(15^{\circ} \mathrm{C}\right)$ for $2 \mathrm{~h} 45 \mathrm{~min} 36 \mathrm{~s}$ without damaging its quality.

\section{Acknowledgements}

The authors thank to Universidade Estadual do Oeste do Paraná (UNIOESTE), Centro de Pesquisa em Aquicultura Ambiental (CPAA) and Conselho Nacional de Desenvolvimento Científico e Tecnológico (CNPq).

\section{References}

ALAVI, S.M.H.; RODINA, M.; POLICAR, T. et al. Semen of Perca fluviatilis L.: sperm volume and density, seminal plasma indices and effects of dilution ratio, ions and osmolality on sperm motility. Theriogenology, v.68, p.276-283, 2007.

BASTARDO, H.; GUEDEZ C.; LEÓN, M. Características del semen de trucha arco-iris de diferentes edades, bajo condiciones de cultivo en Mérida, Venezuela. Zootecnia Tropical, v.22, n.3, p.277-288, 2004.
BILLARD, R.; COSSON, M.P. Some problems related to the assessment of sperm motility in freshwater fish. The Journal of Experimental Zoology, v.261, p.22-31, 1992.

BLOM, E.A. One-minute live-dead sperm stain by means of Eosin-Nigrosin. Fertility and Sterility, v.1, p.176-177, 1950 .

BOMBARDELLI, R.A.; MÖRSCHBÄCHER, E.F.; CAMPAGNOLO, R. et al. Dose inseminante para fertilização artificial de ovócitos de jundiá Rhamdia quelen (Quoy \& Gaimardm, 1824). Revista Brasileira de Zootecnia, v.35, n.4, p.1251-1257, 2006.

BORGES, A.; SIQUEIRA, D.R.; JURINITZ1, D.F. et al. Biochemical composition of seminal plasma and annual variations in semen characteristics of jundia' Rhamdia quelen (Quoy and Gaimard, Pimelodidae). Fish Physiology and Biochemistry, v.31, p.45-53, 2005.

CHEREGUINI, O.; DE LA BANDA, I.G.; RASINES, I. et al. Artificial fertilization in turbot, Scopothalmus maximus, (L.): different methods and determination of the optimal sperm-egg ratio. Aquaculture Research, v.30, p.319-324, 1999.

DENNISTON. R.S.; MICHELET, S.; GODKE, R.A. Principles of Cryopreservation. In: TIERSCH, T.R.; MAZIK, P.M. (Eds.) Cryopreservation in aquatic species. Morgantown: The World Aquaculture Society, 2000. p.59-74.

FERREIRA, A.A.; NUÑER, A.P.O.; LUZ, R.K. et al. Avaliação qualitativa e quantitativa do sêmen de jundiá, Rhamdia quelen. Boletim do Instituto de Pesca, v.27, n.1, p.57-60, 2001.

GODINHO, H.P. Estratégias reprodutivas de peixes aplicadas à aqüicultura: bases para o desenvolvimento de tecnologias de produção. Revista Brasileira de Reprodução Animal, v.31, n.3, p.351-360, 2007.

INSTITUTO BRASILEIRO DO MEIO AMBIENTE E DOS RECURSOS NATURAIS RENOVÁVEIS - IBAMA [2007]. Estatística da pesca 2005: Grandes regiões e unidades da federação. Brasília: Coordenação Geral de Gestão de Recursos Pesqueiros. 2007 147p. Disponível em: <http://www.ibama.gov.br/ rec_pesqueiros> Acesso em: 9/9/2007.

LUZ, R.K.; FERREIRA, A.A.; REYNALTE-TAJATE, D.A. et al. Avaliação qualitativa e quantitativa do sêmen do suruvi, Steindachneridion scripta (pimelodidae). Boletim do Instituto de Pesca, v.27, n.1, p.39-42, 2001.

MARIA, A.N.; MURGAS, L.D.S.; BARBOSA SILVA, M.O. et al. Influência da adição de iodeto de potássio e citrato de sódio na qualidade do sêmen de pacu (Piaractus mesopotamicus Holmberg, 1887). Ciência e Agrotécnologia, v.28, n.1, p.191-194, 2004.

NAKATANI, K.; AGOSTINHO, A.A.; BAUMGARTNER, G. et al. Ovos e larvas de peixes de água doce. Maringá: EDUEM, 2001. 378p.

QUINN, G.P.; KEOUGH, M.J. Experimental design and data analysis for biologists. New York: Cambridge University Press, 2002. 537p.

RINCHARD, J.; DABROWSKI, K.; VAN TASSELL, J.J. et al. Optimization of fertilization success in Sander vitreus is influenced by the sperm: egg ratio and ova storage. Journal of Fish Biology, v.67, p.1157-1161, 2005.

ROMAgOSA, E.; PAIVA, P.; GODINHO, H.M. Pattern of Oocyte Diameter frequency distribution in females of the Pacu, Piaractus mesopotamicus (Holmberg 1887) (=Colossoma mitreiI Berg 1895), induced to spawn. Aquaculture, v.86, p.105-110, 1990 .

RURANGWA, E.; KIME, D.E.; OLLEVIER, F. et al. The measurement of sperm motility and factors affecting sperm quality in cultured fish. Aquaculture, v.234, p.1-28, 2004.

RURANGWA, E.; ROELANTS, I.; HUYSKENS, G. et al. The minimum effective spermatozoa:egg ratio for artificial insemination and the effects of mercury on sperm motility and fertilization ability in (Clarias gariepinus). Journal of Fish Biology, v.53, p.402-413, 1998. 
SANCHES, E.A.; BOMBARDELLI, R.A.; BAGGIO, D.M. et al. Dose inseminante para fertilização artificial de ovócitos de dourado. Revista Brasileira de Zootecnia, v.38, n.11, p.2091-2098, 2009.

SHIMODA, E.; ANDRADE, D.R.; VIDAL JR., M.V. et al. Determinação da razão ótima de espermatozóides por ovócitos de piabanha Brycon insignis (pisces - characidae). Arquivos Brasileiros de Medicina Veterinária e Zootecnia, v.59, n.4, p.877-882, 2007.

SOUZA, B.E. Fertilização artificial de curimbatá Prochilodus lineatus. 2007. 67f. Dissertação (Mestrado em Aquicultura) Universidade Estadual Paulista Júlio de Mesquita Filho, Jaboticabal.

STREIT JR., D.P.; MORAES, G.V.; RIBEIRO, R.P. et al. Comparação do sêmen de curimbá ( Prochilodus lineatus) induzido por extrato de hipófise de frango, coelho ou carpa. Brazilian Journal of Veterinary and Animal Science, v.41, p.147-153, 2004a.

STREIT JR., D.P.; MORAES, G.V.; RIBEIRO, R.P. et al. Avaliação de diferentes técnicas para coloração de sêmen de peixes. Arquivos de Ciências Veterinárias e Zoologia UNIPAR, v.7, n.2, p.157-162, 2004b.

SUQUET, M.; BILLARD, R.; COSSON, J. et al.C.Artificial insemination in turbot (Scophthalmus maximus): determination of the optimal sperm to egg ratio and time of gamete contact. Aquaculture, v.133, p.83-90, 1995.
TVEDT, H.B.; BENFEY, T.J.; MARTIN-ROBICHAUD, D.J. et al. The relationship between sperm density, spermatocrit, sperm motility and fertilization success in Atlantic halibut, hippoglossus hippoglossus. Aquaculture, v.194, p.191-200, 2001.

UNIVERSIDADE FEDERAL DE VIÇOSA - UFV. SAEG Sistema para análises estatísticas e genéticas. Versão, 7,1. Viçosa, MG: UFV, 1997. 150p. (Manual do usuário).

URBINATI, E.C.; GONÇALVES, F.D. Pacu (Piaractus mesopotamicus). In: BALDISSEROTTO B.; GOMES, L.C. (Eds.) Espécies nativas para a piscicultura no Brasil. Santa Maria: EDUFSM, 2005. p.225-255.

VIVEIROS, A.T.M.; GODINHO, H.P. Sperm quality and cryopreservation of Brazilian freshwater fish species: a review. Fish Physiology and Biochemistry, v.35, p.137-150, 2009.

OYNAROVICH, E.; HORVATH, L. Propagação artificial de peixes de águas tropicais: manual de extensão. Trad. Vera Lucia Mixtra Chama. Brasilia: Escopo. 1983. 220p. Tradução de "The artificial propagation of warm - water finfishes - A manual for extension".

ZANIBONI FILHO, E.; WEINGARTNER, M. Técnicas de indução da reprodução de peixes migradores. Revista Brasileira de Reprodução Animal, v.31, n.3, p.367-373, 2007. 